\title{
The crystal chemistry of cowlesite
}

\author{
Giovanna Vezzalini, Gilberto Artioli and Simona Quartieri \\ Istituto di Mincralogia e Petrologia, Università di Modena Via S. Eufemia 19, 41100 Modena, Italy \\ AND \\ HARRY FOY \\ 19 Wynard Park, Belfast BT5 6NS, Northern Ireland
}

\begin{abstract}
Cowlesite specimens from nine new occurrences in Northern Ireland and from eight localities previously reported in the literature, were crystal-chemically characterised. The chemical data for a total of 25 samples indicate a composition close to the stoichiometric formula for cowlesite and a very limited compositional range. X-ray powder diffraction spectra were performed on 8 samples. The crystallographic unit cell permit a proper indexing of the X-ray powder diffraction patterns as orthorhombic, unit cell constants close to $a 23.3, b 30.6, c 25.0 \AA$ and doubled with respect to those originally reported in literature. The powder pattern and the TG curve are reported for an unidentified mineral species associated with cowlesite in one of the samples from Northern Ireland.
\end{abstract}

KEYWORDS: zeolite, cowlesite, electron microprobe analysis, thermal analysis, powder pattern, lattice constants.

\section{Introduction}

Cowlesite (ideally $\mathrm{Ca}_{6} \mathrm{Al}_{12} \mathrm{Si}_{18} \mathrm{O}_{60} \cdot 36 \mathrm{H}_{2} \mathrm{O}$ ) is a calcium-rich zeolite with unknown structure, first described by Wise and Tschernich (1975) from several localities in North America. Other occurrences were reported from Japan (Matsubara et al., 1978; Fujimoto et al., 1990), Iceland and Faeröes (Betz, 1981), Northern Ireland (Nawaz, 1984), Scotland (Gottardi and Galli, 1985), and Australia (Birch, 1988, 1989).

In the literature there is a good agreement as far as the chemical formula unit of cowlesite is concerned, although there is considerable confusion in the definition of the crystallographic cell parameters. All authors agree on the choice of a primitive lattice type and on the orthorhombic unit cell; however, Wise and Tschernich (1975) and Matsubara et al. (1978) originally reported a cell with approximately $a 11.28, b 15.24, c 12.64$ $\AA$, while Nawaz (1984) and Artioli et al. (1988) found the lattice constants of a sample from Ballyclare Quarry (Co. Antrim, Northern Ireland) to be doubled in all directions.

The small size of the crystals and their structural imperfections prevented single crystal data collection with conventional X-ray sources; the determination of the cowlesite structure is at present being attempted on the basis of the X-ray synchrotron data collected by Artioli et al. (1988).

One of us (H. F.) recently found new cowlesite occurrences at several localities in Northern Ireland, and the availability of the specimens prompted the present study with the following aims:

(a) the crystal-chemical characterisation of the new samples;

(b) the comparison with the literature data of other cowlesites and the definition of the chemical variability of the species;

(c) the conclusive definition of the lattice parameters of the zeolite, to establish whether the cell doubling is common to all samples;

(d) the determination of possible correlation among chemical and crystallographic parameters.

\section{Samples studied}

The 25 samples studied in the present work are listed in Table 1 and grouped by locality; the new occurrences are numbered from 1 to 17 and the previously reported occurrences with corresponding literature reference are nos. 18 to 25 .

The habit of the cowlesites from the new occurrences is very similar to the one described 


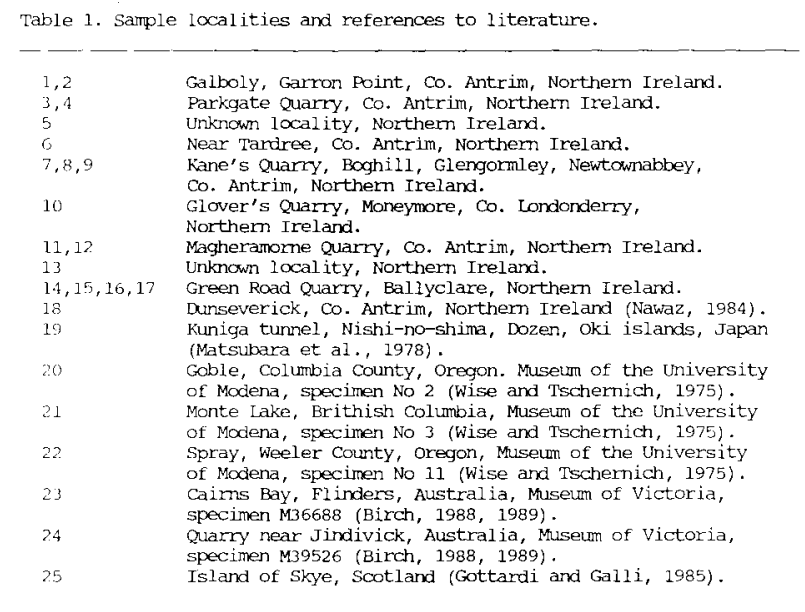

for the other studicd specimens. The zcolite always occurs in white, soft globular linings inside vesicles and fractures of basaltic rocks. Broken hemispheres of the globes show the cowlesite crystals to be very thin radiating plates with pearly lustre. The zeolite is often overgrown on thin saponite film alteration of the vesicle walls and is sometimes associated with analcime or chabazite.

\section{Experimental}

All cowlesite samples were initially identified by $\mathrm{X}$-ray diffraction using a Gandolfi camera.

Electron probe microanalyses were carried out in the wavelength-dispersive mode on an ARLSEMQ instrument opcrated at $15 \mathrm{kV}, 0.20 \mu \mathrm{A}$ beam current and a defocused beam (spot size $\sim 10 \mu \mathrm{m})$. Natural and synthetic silicates were used as standards. On-line data reduction was based on the Ziebold and Ogilvie (1964) method using the Albee and Ray (1970) correction factors.

For nine samples (nos. 1, 5, 6, 7, 10, 11, 12, 14 and 19 in Table 2) the water content was determined by thermogravimetric analysis, using about $8 \mathrm{mg}$ of pure material and a Du Pont thermal analyser, operated in air at a heating rate of $10^{\circ} \mathrm{C} / \mathrm{min}$

The chemical analyses of these nine cowlesites were normalised to $100 \%$ using the water content derived by thermal curves. For the other samples, chemical analysis normalisation to $100 \%$ was performed using a mean water content averaged on the basis of our results and literature data (see Table 2).

Eight samples for which abundant material was available were also characterised by X-ray powder diffraction using an automated Philips goniometer equipped with a pyrolitic graphite analyser crystal. $\mathrm{Cu}-K \alpha$ radiation was used in a step scan mode with $0.02^{\circ}$ steps and $15 \mathrm{~s}$ counting time for each step. Extraction of the angular values for diffraction peaks from the digital

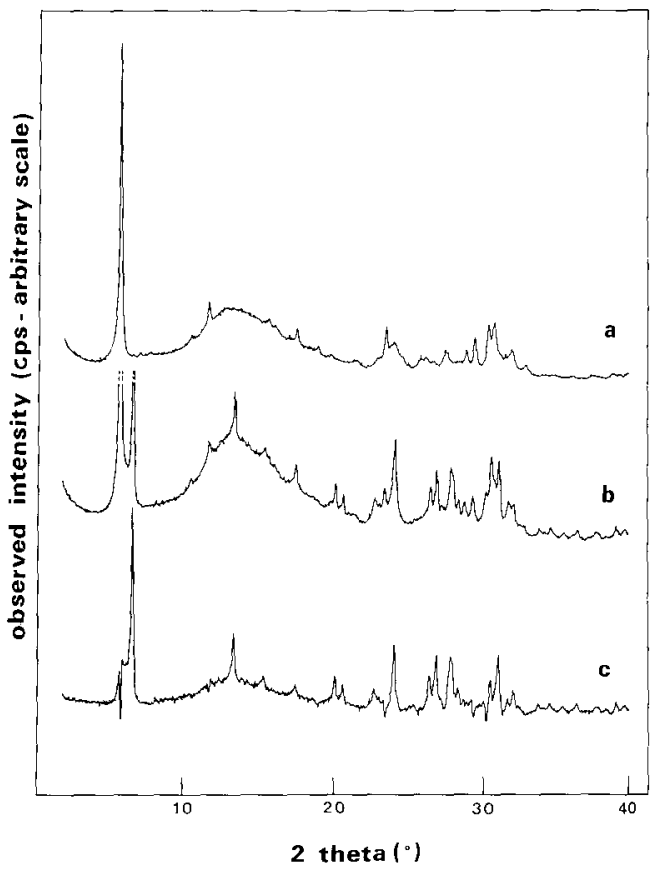

Fici. 1. Observed powder diffraction patterns of $(a)$ cowlesite sample no. 2 and $(b)$ sample no. 6 containing cowlesite and an unidentificd phase. Pattern $(c)$ is the diffraction pattern of the unidentified mineral obtained as difference of $(b)$ and $(a)$. 
Table 2. Chemical analysis, atomic ratios (on the basis 60 oxygens) and crystallographic cell parameters of cowlesites.

\begin{tabular}{|c|c|c|c|c|c|c|c|c|c|c|}
\hline N. & $\mathrm{Na} 2 \mathrm{O}$ & $\mathrm{K} 2 \mathrm{O}$ & MgO & $\mathrm{CaO}$ & $\mathrm{SrO}$ & $\mathrm{BaO}$ & $\mathrm{FeO}$ & $\mathrm{Al} 203$ & $\mathrm{SiO} 2$ & $\mathrm{H} 2 \mathrm{O}$ \\
\hline $\begin{array}{l}1 \\
2 \\
3 \\
4 \\
5 \\
6 \\
7 \\
8 \\
9 \\
10 \\
11 \\
12 \\
13 \\
14 \\
15 \\
16 \\
17 \\
18 \\
19 \\
20 \\
21 \\
22 \\
23 \\
24 \\
25\end{array}$ & $\begin{array}{l}0.95 \\
0.56 \\
0.63 \\
0.55 \\
0.90 \\
0.68 \\
0.51 \\
0.61 \\
0.46 \\
0.94 \\
0.62 \\
0.80 \\
1.03 \\
0.62 \\
0.83 \\
0.66 \\
0.27 \\
1.56 \\
0.62 \\
1.00 \\
0.48 \\
0.79 \\
0.91 \\
0.80 \\
0.38\end{array}$ & $\begin{array}{l}0.09 \\
0.19 \\
0.02 \\
0.09 \\
0.11 \\
0.70 \\
0.30 \\
0.09 \\
0.32 \\
0.07 \\
0.07 \\
0.31 \\
0.20 \\
0.10 \\
0.03 \\
0.05 \\
0.15 \\
0.45 \\
0.07 \\
0.31 \\
0.41 \\
0.07 \\
0.12 \\
0.10 \\
0.29\end{array}$ & $\begin{array}{l}0.24 \\
0.04 \\
0.15 \\
0.13 \\
0.20 \\
0.03 \\
0.03 \\
0.02 \\
0.02 \\
0.18 \\
0.11 \\
0.08 \\
0.17 \\
0.73 \\
0.06 \\
0.09 \\
0.11 \\
0.32 \\
0.23 \\
0.10 \\
0.09 \\
0.08 \\
0.28 \\
0.22 \\
0.08\end{array}$ & $\begin{array}{l}10.65 \\
11.79 \\
12.41 \\
12.32 \\
11.37 \\
11.84 \\
12.09 \\
11.57 \\
11.25 \\
11.75 \\
12.04 \\
11.69 \\
11.43 \\
11.40 \\
11.53 \\
12.23 \\
10.66 \\
11.69 \\
11.06 \\
11.66 \\
11.81 \\
10.47 \\
11.59 \\
11.46\end{array}$ & $\begin{array}{l}0.05 \\
0.01 \\
0.02 \\
0.05 \\
0.03 \\
0.04 \\
0.03 \\
0.02 \\
0.03 \\
0.02 \\
0.01 \\
0.01 \\
0.05 \\
0.02 \\
0.02 \\
0.00 \\
0.02 \\
0.04 \\
0.02 \\
0.02 \\
0.00 \\
0.04 \\
0.05 \\
0.02 \\
0.01\end{array}$ & $\begin{array}{l}0.03 \\
0.01 \\
0.02 \\
0.03 \\
0.01 \\
0.03 \\
0.04 \\
0.02 \\
0.02 \\
0.00 \\
0.02 \\
0.01 \\
0.07 \\
0.01 \\
0.00 \\
0.01 \\
0.02 \\
0.02 \\
0.02 \\
0.03 \\
0.03 \\
0.01 \\
0.05 \\
0.04 \\
0.01\end{array}$ & $\begin{array}{l}0.01 \\
0.05 \\
0.01 \\
0.03 \\
0.10 \\
0.02 \\
0.09 \\
0.02 \\
0.02 \\
0.04 \\
0.00 \\
0.03 \\
0.06 \\
0.01 \\
0.05 \\
0.03 \\
0.02 \\
0.02 \\
0.03 \\
0.02 \\
0.02 \\
0.03 \\
0.14 \\
0.08 \\
0.03\end{array}$ & $\begin{array}{l}23.55 \\
23.46 \\
22.64 \\
22.62 \\
23.44 \\
23.12 \\
23.59 \\
22.75 \\
23.27 \\
22.00 \\
22.84 \\
23.10 \\
22.34 \\
22.86 \\
23.30 \\
22.92 \\
23.52 \\
23.30 \\
22.34 \\
22.86 \\
22.50 \\
22.34 \\
22.91 \\
22.25 \\
22.74\end{array}$ & $\begin{array}{l}42.43 \\
42.19 \\
42.40 \\
42.48 \\
42.04 \\
43.34 \\
42.32 \\
42.20 \\
42.96 \\
42.60 \\
42.09 \\
42.57 \\
42.95 \\
42.25 \\
42.48 \\
42.31 \\
41.79 \\
41.93 \\
43.38 \\
42.90 \\
43.11 \\
43.13 \\
43.32 \\
43.21 \\
43.30\end{array}$ & $\begin{array}{l}22.00 \\
21.70 \\
21.70 \\
21.70 \\
21.80 \\
21.20 \\
21.00 \\
21.70 \\
21.70 \\
22.40 \\
22.20 \\
21.40 \\
21.70 \\
22.60 \\
21.70 \\
21.70 \\
21.70 \\
21.70 \\
21.70 \\
21.70 \\
21.70 \\
21.70 \\
21.70 \\
21.70\end{array}$ \\
\hline
\end{tabular}

\begin{tabular}{|c|c|c|c|c|c|c|c|c|c|c|c|c|c|c|c|}
\hline N. & $\mathrm{Na}$ & $\mathrm{K}$ & $\mathrm{Mg}$ & $\mathrm{Ca}$ & $\mathrm{Sr}$ & $\mathrm{Ba}$ & $\mathrm{Fe}$ & $\mathrm{Al}$ & Si & $\mathrm{H} 2 \mathrm{O}$ & $\mathrm{E}^{\star}$ & $R^{\star \star}$ & $a$ & $\mathrm{~b}$ & $\mathrm{c}$ \\
\hline $\begin{array}{l}1 \\
2 \\
3 \\
4 \\
5 \\
6 \\
7 \\
8 \\
9 \\
10 \\
11 \\
12 \\
13 \\
14 \\
15 \\
16 \\
17 \\
18 \\
19 \\
20 \\
21 \\
22 \\
23 \\
24\end{array}$ & $\begin{array}{l}0.79 \\
0.47 \\
0.53 \\
0.45 \\
0.75 \\
0.56 \\
0.42 \\
0.51 \\
0.38 \\
0.79 \\
0.52 \\
0.67 \\
0.86 \\
0.52 \\
0.69 \\
0.55 \\
0.23 \\
1.31 \\
0.52 \\
0.83 \\
0.40 \\
0.66 \\
0.76 \\
0.67 \\
0.32\end{array}$ & $\begin{array}{l}0.05 \\
0.10 \\
0.01 \\
0.05 \\
0.06 \\
0.38 \\
0.16 \\
0.05 \\
0.17 \\
0.04 \\
0.04 \\
0.17 \\
0.11 \\
0.06 \\
0.02 \\
0.03 \\
0.08 \\
0.25 \\
0.04 \\
0.17 \\
0.22 \\
0.04 \\
0.07 \\
0.06 \\
0.16\end{array}$ & $\begin{array}{l}0.15 \\
0.03 \\
0.10 \\
0.08 \\
0.13 \\
0.02 \\
0.02 \\
0.01 \\
0.01 \\
0.12 \\
0.07 \\
0.05 \\
0.11 \\
0.08 \\
0.04 \\
0.06 \\
0.07 \\
0.21 \\
0.15 \\
0.05 \\
0.06 \\
0.05 \\
0.18 \\
0.14 \\
0.05\end{array}$ & $\begin{array}{l}4.92 \\
5.44 \\
5.74 \\
5.70 \\
5.26 \\
4.96 \\
5.55 \\
5.82 \\
5.17 \\
5.48 \\
5.60 \\
5.38 \\
5.28 \\
5.31 \\
5.31 \\
5.65 \\
5.73 \\
4.94 \\
5.37 \\
5.10 \\
5.38 \\
5.45 \\
4.81 \\
5.34 \\
5.27\end{array}$ & $\begin{array}{l}0.01 \\
0.00 \\
0.01 \\
0.01 \\
0.01 \\
0.01 \\
0.01 \\
0.00 \\
0.01 \\
0.00 \\
0.00 \\
0.00 \\
0.01 \\
0.00 \\
0.00 \\
0.00 \\
0.00 \\
0.01 \\
0.00 \\
0.00 \\
0.00 \\
0.01 \\
0.01 \\
0.01 \\
0.00\end{array}$ & $\begin{array}{l}0.01 \\
0.00 \\
0.00 \\
0.01 \\
0.00 \\
0.00 \\
0.01 \\
0.00 \\
0.00 \\
0.00 \\
0.00 \\
0.00 \\
0.01 \\
0.00 \\
0.00 \\
0.00 \\
0.00 \\
0.00 \\
0.00 \\
0.00 \\
0.00 \\
0.00 \\
0.01 \\
0.01 \\
0.00\end{array}$ & $\begin{array}{l}0.00 \\
0.02 \\
0.00 \\
0.00 \\
0.03 \\
0.01 \\
0.03 \\
0.01 \\
0.01 \\
0.01 \\
0.00 \\
0.01 \\
0.02 \\
0.00 \\
0.02 \\
0.01 \\
0.00 \\
0.01 \\
0.01 \\
0.01 \\
0.01 \\
0.01 \\
0.05 \\
0.03 \\
0.01\end{array}$ & $\begin{array}{l}11.96 \\
11.92 \\
11 . .52 \\
11.51 \\
11.92 \\
11.65 \\
11.90 \\
11.59 \\
11.77 \\
11.28 \\
11.68 \\
11.70 \\
11.36 \\
11.72 \\
11.82 \\
11.66 \\
11.97 \\
11.30 \\
11.60 \\
11.42 \\
11.34 \\
11.58 \\
11.29 \\
11.51\end{array}$ & $\begin{array}{l}18.28 \\
18.18 \\
18.30 \\
18.34 \\
18.14 \\
18.53 \\
18.12 \\
18.24 \\
18.43 \\
18.53 \\
18.26 \\
18.29 \\
18.52 \\
18.37 \\
18.27 \\
18.25 \\
18.04 \\
18.13 \\
18.62 \\
18.46 \\
18.56 \\
18.57 \\
18.57 \\
18.59 \\
18.59\end{array}$ & 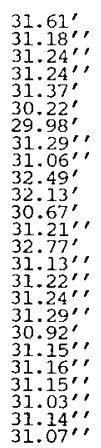 & $\begin{array}{l}+8.6 \\
+3.6 \\
-5.8 \\
-4.9 \\
+3.0 \\
+6.5 \\
+1.6 \\
-5.3 \\
+7.5 \\
-6.1 \\
-1.9 \\
0.0 \\
-3.6 \\
+3.0 \\
+3.6 \\
-2.8 \\
+0.3 \\
+0.1 \\
-2.6 \\
+2.2 \\
-0.7 \\
-3.2 \\
+7.2 \\
-3.4 \\
+3.5\end{array}$ & $\begin{array}{l}0.604 \\
0.604 \\
0.614 \\
0.614 \\
0.603 \\
0.614 \\
0.603 \\
0.611 \\
0.610 \\
0.621 \\
0.610 \\
0.610 \\
0.619 \\
0.611 \\
0.607 \\
0.610 \\
0.601 \\
0.604 \\
0.622 \\
0.614 \\
0.619 \\
0.621 \\
0.615 \\
0.622 \\
0.617\end{array}$ & $\begin{array}{l}23.27(1) \\
23.26(2) \\
23.21\left\{\begin{array}{l}2 \\
23.30 \\
1\end{array}\right\} \\
23.28(1) \\
23.23\left\{\begin{array}{l}1 \\
23.25(1) \\
23.26(1)\end{array}\right.\end{array}$ & $\begin{array}{l}\begin{array}{l}30.61 \\
30.68 \\
30.66\end{array}\left\{\begin{array}{l}2 \\
2 \\
1\end{array}\right\} \\
\left.\begin{array}{l}30.60\left(\begin{array}{l}1 \\
30.63 \\
1\end{array}\right. \\
30.64(1) \\
30.62(1)\end{array}\right\}\end{array}$ & $\begin{array}{l}\begin{array}{l}25.02 \\
25.02 \\
25.04\end{array}\left\{\begin{array}{l}1 \\
1\end{array}\right\} \\
24.98\left\{\begin{array}{l}1 \\
25.01 \\
25.02(1) \\
25.00(2)\end{array}\right.\end{array}$ \\
\hline
\end{tabular}

$* \underset{R}{E}=\{[\mathrm{Al}-(\mathrm{M}+2 \mathrm{D})] /(\mathrm{S}+\mathrm{M}+\mathrm{AD}+\mathrm{Fe})\} \times 100$; where $\mathrm{M}=\mathrm{Na}+\mathrm{K}$ and $\mathrm{D}=\mathrm{Mg}+\mathrm{Ca}+\mathrm{Sr}+\mathrm{Ba}$

$\therefore$ water content from TG analysis

diffraction patterns was obtained using the centroid of the second derivative function. Table 3 lists the unambiguous reflections identified in the cowlesite pattern up to $40^{\circ} 2 \theta$ and the diffraction-peaks of an unknown phase present in sample no. -6 . Fig. 1 shows the characteristic spectrum of cowlesite (sample no. 2) compared with the pattern of sample no. 6 . The TG curve of this sample, performed on the same powder used for the X-ray diffraction, shows a small shift of the first endothermal peak to lower temperature and an additional peak at about $200^{\circ} \mathrm{C}$.

\section{Discussion and conclusions}

On the basis of the chemical data of cowlesites we can deduce that:

- the tetrahedral cations have nearly constant ratio, with $\mathrm{Si} /(\mathrm{Si}+\mathrm{Al}+\mathrm{Fc})$ values ranging from 0.603 to 0.622 ;

-the extra-framework cations are represented mainly by $\mathrm{Ca}$; $\mathrm{Na}$ is present as a minor component and $\mathrm{K}$ and $\mathrm{Mg}$ are always less than $8 \%$ of the total cation content;

$-\mathrm{Fe}, \mathrm{Sr}$ and $\mathrm{Ba}$ are present in trace level;

- the water content found by TG analysis is quite constant, ranging from 30.22 to 32.77 water molecules p.f.u., and significantly less than the value usually reported for cowlesite ( 36.0 water molecules p.f.u.).

The results complement the few analyses reported in the literature and indicate a chemical composition close to the stoichiometric formula with a very narrow compositional range. Moreover, no evidence for statistically significant correlation between the chemical parameters was found by multivariate analysis of the compositional data (SPSS-X Statistical Algorithms, 1983).

On the basis of the $\mathrm{Si} / \mathrm{Al}$ ratio (very near to $3 / 2$ ) and the presence of $\mathrm{Ca}$ as the main extraframework cation, it is plausible to predict an 


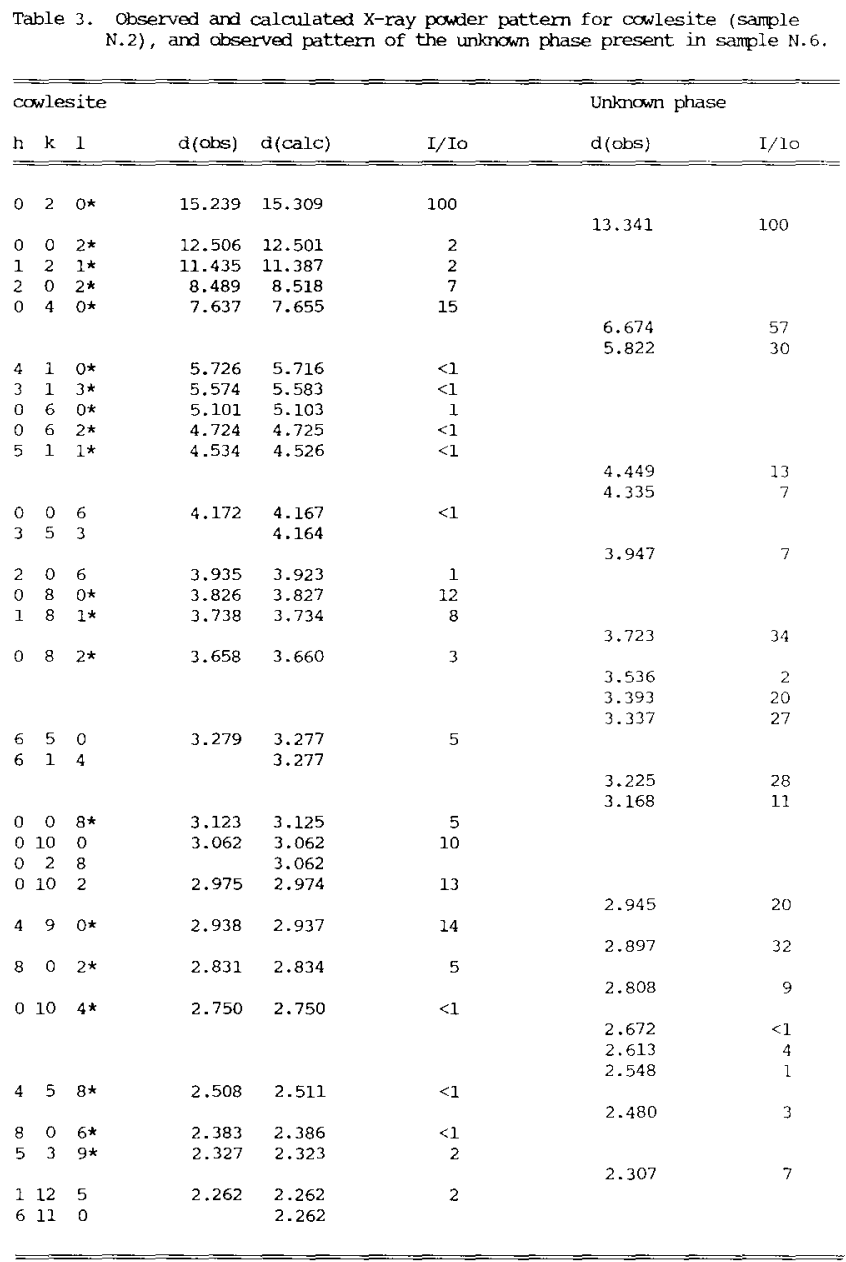

* Reflections used in the refinement of the cell parameters.

ordered $(\mathrm{Si}, \mathrm{Al})$ distribution in the tetrahedral framework of cowlesite (Alberti, 1991), probably controlled by the 'extended Loewenstein's rule' (Merlino, 1984), because of the low $\mathrm{Si} /(\mathrm{Si}+\mathrm{Al}$ ) ratio. It is worth noting that the cowlesite formula unit resembles that of scolecite, apart from the water content.

As far as the cell parameters are concerned, careful analysis of the powder pattern using computer graphics and profile fitting showed that about 30 diffraction peaks below $40^{\circ} 2 \theta$ are well resolved and characteristic of all cowlesite samples. The intensities of all these peaks are in agreement with those derived from the singlecrystal study of the Ballyclare sample (Artioli et al., 1988).

The diffraction peaks common to all analysed samples were indexed taking into account their angular dispersion and index probability parameter derived from the calculation of the multiplicity of the reflection with the structure factors available from the single crystal study. The same 20 unambiguously indexed diffraction peaks for all samples were used to determine the cell constants by least-squares refinement.

The diffraction peaks of the unknown species present in sample no. 6, obtained after digital subtraction of the rescaled cowlesite diffraction pattern (Fig. 1 and Table 3 ) clearly shows at least 10 to 20 peaks not related to any reported mineral phase in sets 1-40 of the PDF-2 Data base. The difficulty in distinguishing the unknown phase from cowlesite by optical observation made its chemical characterisation impossible. 


\section{Acknowledgements}

Financial support is acknowledged from the Italian Consiglio Nazionale delle Ricerche and Ministero dell'Università e della Ricerca Scientifica c Tecnologica. Computing time was made available from the Centro Interdipartimentale di Calcolo Automatico ed Informatica Applicata' of the University of Modena. The Consiglio Nazionale delle Ricerche of Italy is also acknowledged for financing the Electron Microprobe Laboratory at the Istituto di Mineralogia e Petrologia of the University of Modena, whose facilitics were used in the present work. We would like to express our appreciation to Dr W. D. Birch (Department of Mineralogy and Petrology, Museum of Victoria, Melbourne, Australia) and Prof. Rinaldi (Dipartimento d Scienze della Terra, Perugia, Italy) for providing some of the cowlesite samples.

\section{References}

Albee, A. L. and Ray, L. (1970) Anal. Chem., 42. $1408-14$.

Alberti, A. (1991) Proc. Int. Symposium on Chemistry of microporous crystals, Kodansha Ltd, Tokyo. 107-22.

Artioli, G., Gottardi, G., Rinaldi, R.. Satow, Y.,
Horiuchi, H., Ye, J., Sawada, H., Tanaka, M., and Tokonami, M. (1988) Photon Factory Activity Report, KEK, proposal No. 87-086.

Betz, V. (1981) Mineral. Record., 12, 5-26.

Birch, W. D. (1988) Austral. Mineral, 3(1), 9-11.

- (1989) Zeolites of Victoria, Mineral. Soc. Victoria, Special Publ. no. 2.

Fujimoto, M.. Matsubara. S., and Nishido, H. (1990) Chigaku Kenkyu, 39(4), 219-24 (in Japanese).

Gottardi, G. and Galli, E. (1985) Natural zeolites, Springer-Verlag Editors, Berlin Heidelberg.

Matsubara, S. Tiba, T., and Kato, A. (1978) Bull. Natn. Sci. Mus, ser. C (Geol), 4(2), 33-6.

Mcrlino. S. (1984) Proc. 6th Int. Conf. on Zeolites (Bisio, A. and Olson, D. H., cds.), Butterworth, Guildford, 747-59.

Nawaz, R. (1984) Mineral. Maty., 48, 565-6.

SPSS-X Statistical Algorithms (1983) SPSS Inc. Chicago.

Wise, W. S. and Tschernich, R. W. (1975) Amer. Mineral., 60, 951-6.

Ziebold, T. O. and Ogilvie, R. E. (1964) Anal. Chem., 36, 322-7.

[Manuscript received 28 November 1991:

revised 25 January 19921 